\title{
Correction
}

\section{Comparison of memory fMRI response among normal, MCI, and Alzheimer's patients}

In the article "Comparison of memory fMRI response among normal, MCI, and Alzheimer's patients" by M.M. Machulda et al. (Neurology 2003;61:500-506), there are errors in the first two sentences in the Results section of the abstract; they should read as follows: "Results: Medial temporal lobe activation was greater in normal subjects than MCI and $\mathrm{AD}$ patients $(p=0.03$ and $p=0.04)$. There was no difference between $\mathrm{AD}$ and MCI patients in fMRI memory performance."

\section{ACTIVATE YOUR ONLINE SUBSCRIPTION}

At www.neurology.org, subscribers can now access the full text of the current issue of Neurology and back issues to 1999. Select the "Login instructions" link that is provided on the Help screen. Here you will be guided through a step-by-step activation process.

Neurology online offers:

- Access to journal content in both Adobe Acrobat PDF or HTML formats

- Links to PubMed

- Extensive search capabilities

- Complete online Information for Authors

- Examinations on designated articles for CME credit

- Access to in-depth supplementary scientific data 


\section{Neurology}

\section{Comparison of memory fMRI response among normal, MCI, and Alzheimer's patients Neurology 2003;61;1164 \\ DOI 10.1212/WNL.61.8.1164}

This information is current as of October 27, 2003

$\begin{array}{ll}\begin{array}{l}\text { Updated Information \& } \\ \text { Services }\end{array} & \begin{array}{l}\text { including high resolution figures, can be found at: } \\ \text { http://n.neurology.org/content/61/8/1164.1.full }\end{array} \\ \text { Permissions \& Licensing } & \begin{array}{l}\text { Information about reproducing this article in parts (figures,tables) or in } \\ \text { its entirety can be found online at: } \\ \text { http://www.neurology.org/about/about_the_journal\#permissions }\end{array} \\ & \begin{array}{l}\text { Information about ordering reprints can be found online: } \\ \text { http://n.neurology.org/subscribers/advertise }\end{array}\end{array}$

Neurology ${ }^{\circledR}$ is the official journal of the American Academy of Neurology. Published continuously since 1951, it is now a weekly with 48 issues per year. Copyright . All rights reserved. Print ISSN: 0028-3878. Online ISSN: 1526-632X.

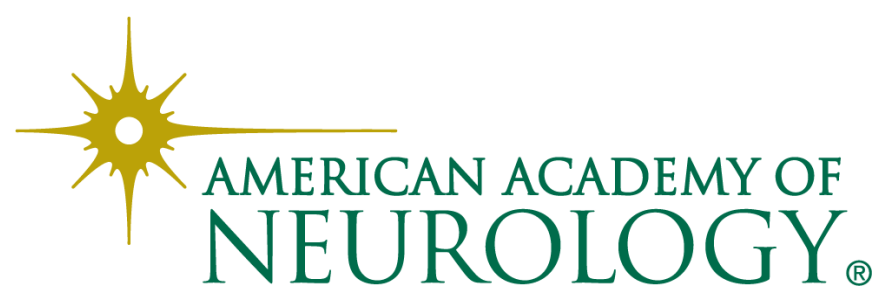

